\title{
Selection of TAVI prostheses: do we really have the CHOICE?
}

Mohamed Abdel-Wahab*, MD; Gert Richardt, MD

Heart Center, Segeberger Kliniken, Bad Segeberg, Germany

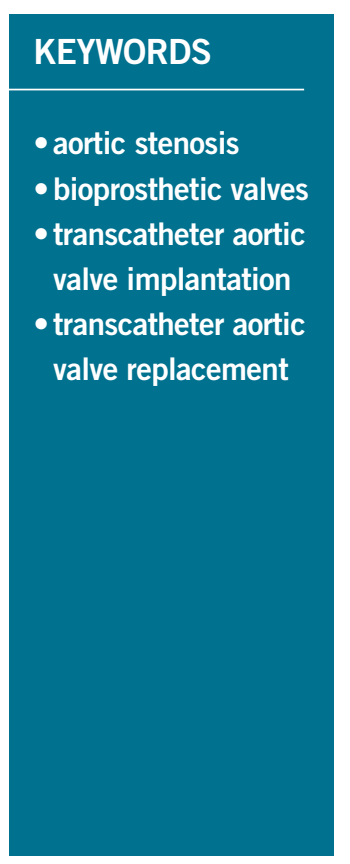

\section{Abstract}

Transcatheter aortic valve implantation (TAVI) has developed rapidly in the past few years and is expected to expand further in the near future. A reasonable number of large multicentre registries and randomised clinical trials have been performed, which have provided a considerable quality of evidence necessary to ensure optimal use and optimal patient outcomes. Currently, a large number of different valves have been approved in Europe, with a varying amount of supporting evidence, which complicates the process of valve type selection. This article reviews the evolution and fundamental aspects of prosthesis type selection in patients undergoing TAVI, and summarises the most relevant clinical studies in this context.

\footnotetext{
*Corresponding author: Heart Center, Segeberger Kliniken GmbH, Academic Teaching Hospital of the Universities of Kiel and Hamburg, Am Kurpark 1, 23795 Bad Segeberg, Germany.E-mail: mohamed.abdel-wahab@segebergerkliniken.de
} 


\section{Introduction}

In 2002, transcatheter aortic valve implantation (TAVI) was performed for the first time in a human by Alain Cribier ${ }^{1}$. The valve used was constructed of bovine pericardium sewn inside a balloonexpandable (BE) stainless steel stent ${ }^{1,2}$. A few years later, Grube et al reported the first-in-human TAVI with a self-expandable (SE) device $^{3}$. Subsequently, technological refinements of both BE and SE prostheses were reported, and successful implantation was repeatedly documented in observational registries ${ }^{2,4-6}$. On the basis of registry data, the SE CoreValve (Medtronic Inc., Minneapolis, $\mathrm{MN}$, USA) received CE mark approval for transfemoral implantation in 2007, followed by the BE Edwards SAPIEN transcatheter heart valve (Edwards Lifesciences, Irvine, CA, USA) in 2008.

\section{Selection of TAVI prostheses: the early days}

Soon after commercialisation, the majority of European centres started their TAVI programme with either one of the two devices. The SE CoreValve (porcine pericardial tissue, long self-expanding nitinol frame) was available in $18 \mathrm{Fr}$ and in 26 and $29 \mathrm{~mm}$ sizes, while the BE Edwards SAPIEN valve (bovine pericardial tissue, short stainless steel frame) was available in 22-24 Fr and in 23 and $26 \mathrm{~mm}$ sizes. Consequently, in the limited number of centres using both technologies at that time, device selection was largely based on the size of the iliofemoral arteries (favouring the SE device in small-sized vessels), and the size of the native aortic annulus (favouring the SE device in large anatomies). Notably, valve sizing was largely based on two-dimensional measurements obtained from echocardiography. In a study reporting TAVI outcomes from a single centre offering all possible combinations for transcatheter treatment using both devices available at that time and three types of access (transapical for the BE device, transsubclavian for the SE device, and transfemoral for both), the procedural success rate was $92.7 \%{ }^{7}$. The authors emphasised that the availability of two different devices, delivered via three different approaches, had made the TAVI procedure increasingly feasible for a wider range of high-risk patients with severe aortic stenosis.

A few years later (in 2010), the newer-generation BE Edwards SAPIEN XT valve (Edwards Lifesciences) received CE mark approval. This modified version with a cobalt-chromium frame offered a reduced sheath size of 18-20 Fr for the transfemoral route. Shortly thereafter, a full size matrix of prostheses became available for both $\mathrm{BE}$ and SE devices. Consequently, the number of centres utilising both technologies steadily increased, and the number of patients treatable with either device increased in parallel. In addition, the recognition of the complex anatomical nature of the aortic valve, annulus and root has sparked a paradigm shift in pre-procedural imaging, moving towards three-dimensional valve sizing largely based on multislice computed tomography (MSCT), which substantially reduced procedural complications such as paravalvular leaks with both devices ${ }^{8,9}$. Selection of TAVI prostheses was then strongly dependent both on operators' familiarity with the device and on certain anatomical and clinical factors that were thought to favour one device over the other. For instance, patients with an impaired left ventricular function were commonly treated with the SE valve to avoid the prolonged periods of rapid ventricular pacing required for the implantation of the $\mathrm{BE}$ valve.

\section{Registry data on balloon- and self-expandable valves}

Subsequently, a number of multicentre registries reported on the comparative short-term performance of both prostheses ${ }^{10-16}$. A summary of these registry data is shown in Table 1. In brief, major clinical outcome measures such as mortality and stroke were comparable with both technologies. The need for a new permanent pacemaker was consistently higher with the SE device, which could be explained by the interaction of its long nitinol frame with the left ventricular septum.

Another finding frequently observed in the majority of these registries was the higher rate of residual more-than-mild aortic regurgitation (AR) with the SE device. The reported incidence ranged from 1.5 to $39 \%$ for the SE device and 0.5 to $22 \%$ for the BE device. A similar observation was reported in a meta-analysis conducted by Athappan and colleagues, where the incidence of more-thanmild AR was $16.0 \%$ with the SE CoreValve device compared to $9.1 \%$ with the BE Edwards SAPIEN valve $(\mathrm{p}=0.005)^{17}$. However, as registry results are naturally hampered by bias and confounding

Table 1. Summary of selected short-term outcome measures in multicentre registries comparing balloon- and self-expandable TAVI prostheses.

\begin{tabular}{|c|c|c|c|c|c|c|c|c|}
\hline & \multicolumn{2}{|c|}{ Mortality* } & \multicolumn{2}{|c|}{ Stroke* } & \multicolumn{2}{|c|}{ New pacemaker } & \multicolumn{2}{|c|}{ More-than-mild $A R^{* *}$} \\
\hline & BE & SE & BE & SE & BE & SE & BE & SE \\
\hline UK TAVI registry ${ }^{10}$ & $8.5 \%$ & $5.8 \%$ & $4.2 \%$ & $4.0 \%$ & $7.4 \%$ & $24.4 \%$ & $9.6 \%$ & $17.3 \%$ \\
\hline FRANCE 2 registry ${ }^{11}$ & $9.6 \%$ & $9.4 \%$ & $3.8 \%$ & $4.3 \%$ & $11.5 \%$ & $24.2 \%$ & $13.0 \%$ & $21.5 \%$ \\
\hline European Sentinel ${ }^{12}$ & $7.9 \%$ & $6.7 \%$ & $1.7 \%$ & $2.1 \%$ & $6.0 \%$ & $23.4 \%$ & $6.7 \%$ & $12.2 \%$ \\
\hline Canadian registry ${ }^{14}$ & NA & NA & NA & NA & NA & NA & $22.0 \%$ & $39.0 \%$ \\
\hline PRAGMATIC Plus ${ }^{13}$ & $6.4 \%$ & $8.8 \%$ & $1.0 \%$ & $2.9 \%$ & $7.4 \%$ & $24.4 \%$ & $0.5 \%$ & $1.5 \%$ \\
\hline BSBK registry ${ }^{15}$ & NA & NA & NA & NA & NA & NA & $18.1 \%$ & $32.5 \%$ \\
\hline GARY 16 & $5.8 \%$ & $4.3 \%$ & NA & NA & NA & NA & NA & NA \\
\hline
\end{tabular}

* Mortality and stroke rates are at hospital discharge for the European Sentinel registry and GARY and at 30 days for all other registries. **AR as assessed by angiography in the UK TAVI and BSBK registries and by echocardiography in all other registries. AR: aortic regurgitation; BE: balloon-expandable; BSBK: Bad Segeberg-Bad Krozingen; GARY: German Aortic Valve Registry; PRAGMATIC: Pooled-RotterdAm-Milano-Toulouse In Collaboration; SE: selfexpandable; TAVI: transcatheter aortic valve implantation; UK: United Kingdom 
factors, these differences were interpreted with caution. In addition, improvements in pre-procedural imaging and device size selection, refinements in implantation technique, and the recognition of paravalvular leaks as a relevant clinical complication ${ }^{18-20}$ were important developments with a potential impact on the functional outcome of both valves. Importantly, most of these registries have reported on AR using site-reported echocardiography or angiography, and core laboratory adjudication was only performed in the Canadian study ${ }^{14}$

On the other hand, rare but life-threatening complications such as annular rupture or acute coronary obstruction seemed to be higher with the $\mathrm{BE}$ valve ${ }^{21}$, especially in patients with adverse root features such as extensive subannular calcification and with extreme prosthesis oversizing ${ }^{22}$.

\section{The randomised US trials}

Regulatory approval in the United States has lagged considerably behind Europe, as the results of randomised clinical trials were awaited. The Placement of AoRTic TraNscathetER Valves (PARTNER) trials were the first prospective randomised landmark studies, which compared TAVI using the earlier-generation BE Edwards SAPIEN device with medical management in inoperable patients (PARTNER Trial Cohort IB) ${ }^{23,24}$, and with surgical aortic valve replacement in patients considered to be at high surgical risk (PARTNER Trial Cohort IA) ${ }^{20,25}$. Based on the results of both trials, the United States Food and Drug Administration (FDA) approved the BE Edwards SAPIEN device for inoperable patients in November 2011, and for high-risk operable candidates in October 2012.

For the SE CoreValve device, the results of two analogous studies were recently reported ${ }^{26,27}$. The non-randomised CoreValve US Pivotal Trial extreme risk study compared TAVI with the SE CoreValve to a pre-specified objective performance goal in inoperable patients, while the randomised CoreValve US Pivotal Trial high risk study compared TAVI using the same device with surgical aortic valve replacement in patients at high risk for surgery. Based on the results of both studies, the FDA approved the SE CoreValve device for inoperable patients in January 2014, and for high-risk operable patients in June 2014.

Following the publication of the CoreValve US trials, device comparisons were again performed utilising the reported outcome measures from both the PARTNER and the CoreValve US trials. The fact that the superiority of TAVI compared to surgical valve replacement was only demonstrated with the SE device and not with the BE device sparked a great deal of discussion. A summary of the most relevant findings from the four published studies is provided in Table 2. Notably, and contrary to the European and Canadian registry data, residual AR seemed to be comparable with both devices, with even a slightly lower incidence with the SE device (especially at one year), suggesting an improvement in paravalvular AR over time with the SE device. It is important to mention here that sizing in the PARTENR I trial was based on two-dimensional echocardiography as opposed to three-dimensional MSCT in the CoreValve US trial. In addition, the obligatory presence of an on-site proctor in the CoreValve US trial may have positively influenced the reported outcome. Finally, inter-trial comparisons remain difficult to perform and, in a rapidly advancing field such as TAVI, continuous improvements in patient selection, imaging and implantation techniques render comparisons of trials performed a few years apart extremely problematic.

\section{The CHOICE trial}

To date, the Comparison of Transcatheter Heart Valves in High Risk Patients With Severe Aortic Stenosis: Medtronic CoreValve vs. Edwards SAPIEN XT (CHOICE) trial ${ }^{28}$ is the only randomised clinical trial comparing BE and SE valves, albeit only for the transfemoral route. The trial partially fills the void of randomised device comparisons described above. CHOICE included 241 patients at five German centres experienced in implanting either valve. The design of the trial is summarised in Figure 1. The primary endpoint of the trial was device success, which is a composite endpoint comprising four components: successful vascular access and deployment of the device and retrieval of the delivery system; correct position of the device; intended performance of the heart valve without moderate or severe regurgitation; and only one valve implanted in the proper anatomical location. The correlation of device success to one-year survival has recently been described ${ }^{15}$. In CHOICE, implantation of a $\mathrm{BE}$ valve resulted in a higher device success rate than the SE valve, with device success in 116 of 121 patients $(95.9 \%)$ in the BE valve group, and 93 of 120 patients (77.5\%) in the SE valve group (relative risk [RR] 1.24, 95\% CI: $1.12-1.37, \mathrm{p}<0.001)$. This was attributed to a significantly lower frequency of residual more-than-mild aortic regurgitation $(4.1 \% \mathrm{vs}$. $18.3 \%$, RR $0.23,95 \%$ CI: $0.09-0.58, \mathrm{p}<0.001)$ and the less frequent

Table 2. Summary of selected outcome measures in the PARTNER I and CoreValve US trials for balloon- and self-expandable TAVI prostheses.

\begin{tabular}{|c|c|c|c|c|c|c|c|c|}
\hline & \multicolumn{2}{|c|}{ Mortality } & \multicolumn{2}{|c|}{ Stroke } & \multicolumn{2}{|c|}{ New pacemaker } & \multicolumn{2}{|c|}{ More-than-mild AR* } \\
\hline & 30-day & 1-year & 30-day & 1-year & 30-day & 1-year & 30-day & 1-year \\
\hline PARTNER IB ${ }^{23}$ & $5.0 \%$ & $30.7 \%$ & $6.7 \%$ & $10.0 \%$ & $3.4 \%$ & $4.5 \%$ & $15.0 \%$ & $15.0 \%$ \\
\hline PARTNER IA ${ }^{25}$ & $3.4 \%$ & $24.2 \%$ & $4.7 \%$ & $6.0 \%$ & $3.8 \%$ & $5.7 \%$ & $13.1 \%$ & $7.1 \%$ \\
\hline CoreValve US extreme risk ${ }^{26}$ & $8.4 \%$ & $24.3 \%$ & $4.0 \%$ & $7.0 \%$ & $21.6 \%$ & $26.2 \%$ & $15.3 \%$ & $6.4 \%$ \\
\hline CoreValve US high risk ${ }^{27}$ & $3.3 \%$ & $14.2 \%$ & $4.9 \%$ & $8.8 \%$ & $19.8 \%$ & $22.3 \%$ & $10.0 \%$ & $7.0 \%$ \\
\hline
\end{tabular}

*Total AR as assessed by core laboratory echocardiography. AR: aortic regurgitation; PARTNER: Placement of AoRTic TraNscathetER Valves; TAVI: transcatheter aortic valve implantation 


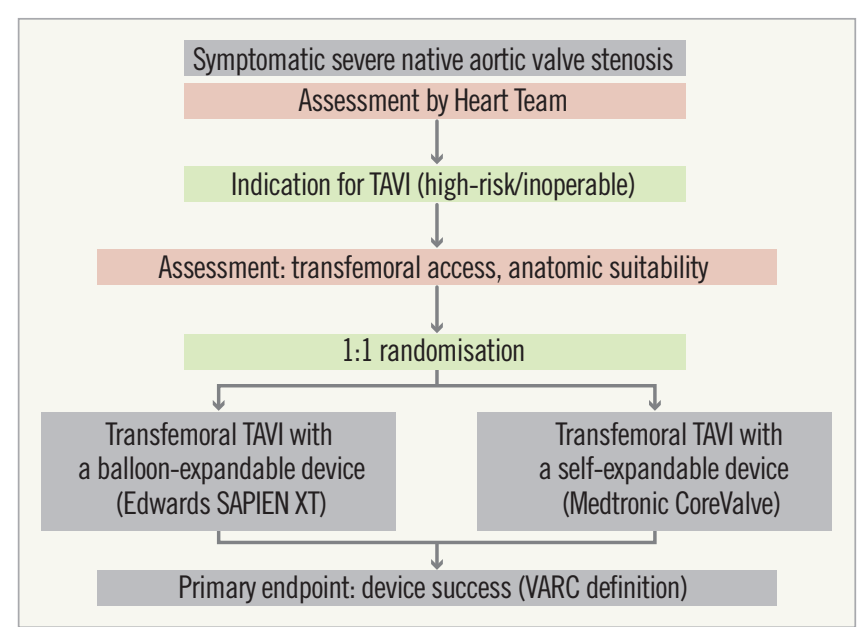

Figure 1. Design of the CHOICE trial ${ }^{28}$. TAVI: transcatheter aortic valve implantation; VARC: Valve Academic Research Consortium

need for implanting more than one valve $(0.8 \%$ vs. $5.8 \%, \mathrm{p}=0.03)$ in the BE valve group. Placement of a new permanent pacemaker was also less frequent in the BE valve group (17.3\% vs. $37.6 \%$, $\mathrm{p}=0.001$ ). With the study being relatively small, there was no difference in 30 -day mortality rates $(4.1 \%$ in the BE valve group and $5.1 \%$ in the SE valve group).

In the CHOICE trial, methods to quantify AR were carefully selected, and included core laboratory angiographic assessment with predefined methods, haemodynamic assessment, echocardiography and magnetic resonance imaging (MRI) ${ }^{28}$. Choosing angiography as the primary tool for AR assessment was partly based on the better correlations observed with angiography than with echocardiography when both were compared to quantitative cardiac MRI ${ }^{29}$. Notably, the differences in AR between BE and SE valves were observed despite adequate annulus sizing using three-dimensional annular measurements and proper high deployment of the SE valve. Furthermore, and contrary to popular belief, the performance of the SE valve was particularly poor in patients with large anatomies and those with heavily calcified aortic valve leaflets (Figure 2), which may be related to the suboptimal radial force of the nitinol stent frame. The more frequent need for a second valve in the SE valve group was in line with previous registry data ${ }^{11-13}$, and supports the notion that newer-generation repositionable valves will be particularly helpful for the SE technology.

The differences in device success between both devices seemed to affect how patients felt after the procedure. The functional class improvement (94\% for BE vs. $87 \%$ for SE), readmission rates for heart failure ( $0 \%$ for BE vs. $4.3 \%$ for $\mathrm{SE})$, and the quality-of-life score (71/100 for BE vs. $66 / 100$ for SE) at 30 days were slightly better for the $\mathrm{BE}$ valve compared with the $\mathrm{SE}$ valve. However, mortality rates at short-term follow-up were comparable, while long-term follow-up data are still pending. Therefore, whether the observed differences in an endpoint such as device success will translate into a long-term clinical superiority of one device over the other is unknown and remains to be determined, especially as paravalvular leaks in SE devices may improve over time, as has been recently suggested in the CoreValve US trial ${ }^{26,27}$.

On the other hand, mean transvalvular gradient was slightly but significantly higher in the $\mathrm{BE}$ valve group $(8.9 \mathrm{mmHg}$ vs. $6.6 \mathrm{mmHg}, \mathrm{p}<0.001$ ), and minor stroke and coronary occlusion were numerically (but not statistically) higher. In addition, patient

\begin{tabular}{|c|c|c|c|c|c|}
\hline \multicolumn{3}{|c|}{ №. of events/total (\%) } & & \multirow[t]{2}{*}{ Risk ratio (95\% Cl) } & \multirow[t]{2}{*}{$p$ for interaction } \\
\hline & Balloon-expandable & Self-expandable & & & \\
\hline Gender & & & & & 0.22 \\
\hline Female & $66 / 69(95.6)$ & $72 / 86(83.7)$ & $\longrightarrow$ & $1.14(1.03-1.27)$ & \\
\hline Male & $50 / 52(96.1)$ & 21/34 (61.8) & - & $1.56(1.19 \cdot 2.04)$ & \\
\hline CT annulus diam & & & & & 0.23 \\
\hline$<25 \mathrm{~mm}$ & $56 / 60(93.3)$ & $55 / 68(80.9)$ & $\longrightarrow$ & 1.15 (1.01-1.32) & \\
\hline$\geq 25 \mathrm{~mm}$ & $34 / 35(97.1)$ & $18 / 26(69.2)$ & $\longrightarrow$ & $1.40(1.08-1.82)$ & \\
\hline Leaflet calcificat & & & & & 0.28 \\
\hline No/mild & $8 / 9(88.9)$ & $17 / 20(85.0)$ & - & $1.04(0.78-1.41)$ & \\
\hline \multirow[t]{3}{*}{ Moderate/severe } & $81 / 85$ (95.3) & $56 / 73(76.7)$ & $\longrightarrow$ & $1.24(1.09-1.42)$ & \\
\hline & & 0.5 & 1 & & \\
\hline & & Self-expandable better & Balloon-expandable better & & \\
\hline
\end{tabular}

Figure 2. Selected subgroup analyses for device success from the CHOICE trial. Selected subgroup analyses are shown for the primary endpoint of device success among patients who were randomly assigned to undergo transfemoral TAVI with either a balloon-expandable or a self-expandable prosthesis. The p-value for interaction represents the likelihood of interaction between the variable and the relative treatment effect. Odds ratios are for the balloon-expandable vs. self-expandable device ${ }^{28}$. CT: computed tomography 
subsets not studied in this trial where SE valves may have benefit include valve-in-valve for small degenerated bioprosthetic aortic valves (less residual gradients due to supra-annular valve function $)^{30}$, and patients with minimal calcification of the aortic valve with predominant regurgitation ${ }^{31}$. These and other points may be critical in deciding which valve to use in a given patient.

\section{Selection of TAVI prostheses: where do we stand now?}

While prosthesis selection was mainly dictated by the dimensions and specifications of the delivery sheath, the delivery catheter and the anatomical limitations of the available prosthesis sizes in the early days, in contemporary clinical practice, operators are mainly focusing on prosthesis specifications such as frame height, design, radial force and anatomical aortic annulus and root characteristics. A reasonable number of large multicentre registries and randomised clinical trials performed in the last few years have provided a considerable quality of evidence necessary to ensure optimal use and optimal patient outcomes after TAVI. The totality of evidence - at least for the transfemoral route - shows that BE valves allow precise device positioning and have a predictable short-term outcome in a wide range of patients and anatomies, with fewer paravalvular leaks and less need for permanent pacing. However, device iterations should aim at improved haemodynamics and optimising stroke rates. In this context, the new-generation BE SAPIEN 3 valve (Edwards Lifesciences) holds some promise.

On the other hand, an ideal self-expandable TAVI device should be completely repositionable/retrievable to allow accurate device positioning. Device iterations should aim at optimising radial force to provide a better seal in large anatomies and extensive calcification, but should probably maintain the advantage of a supra-annular leaflet function, which is associated with excellent haemodynamics.

With the tremendous amount and pace of progress with TAVI, ten different valves have now been approved in Europe, which makes the process of valve choice even more complicated. While the fundamental characteristics of the valves remain unchanged, newer technologies such as mechanically expanding valves (Lotus; Boston Scientific Corporation, Natick, MA, USA) and non-metallic devices (Direct Flow Medical ${ }^{\circledR}$; Direct Flow Medical Inc., Santa Rosa, CA, USA) have entered the field and are searching for their indications. Despite their theoretical advantages, all of these "newcomers" are supported by a modest amount of scientific evidence. In addition, procedure-related factors, such as access route, balloon pre-dilatation and periprocedural imaging, sometimes remain controversial.

The majority of TAVI patients will probably be treatable with one valve type. Nevertheless, an expanded device armamentarium is necessary to ensure treatment of the complete spectrum of patients considered for TAVI. In addition, because operator experience is an important factor in ultimate success, local expertise has to be considered when selecting the valve type. The results of the CHOICE trial are important, but currently cannot be interpreted as a surrogate for long-term outcomes, and the question of device durability is still unanswered. Long-term follow-up data and additional rigorous randomised studies are necessary to optimise further selection and use of the currently available devices.

\section{Conflict of interest statement}

M. Abdel-Wahab and G. Richardt report receiving an institutional research grant from Medtronic and lecture fees from Boston Scientific. G. Richardt reports receiving lecture fees from Edwards Lifesciences.

\section{References}

1. Cribier A, Eltchaninoff H, Bash A, Borenstein N, Tron C, Bauer F, Derumeaux G, Anselme F, Laborde F, Leon MB. Percutaneous transcatheter implantation of an aortic valve prosthesis for calcific aortic stenosis: first human case description. Circulation. 2002;106:3006-8.

2. Webb JG, Chandavimol M, Thompson CR, Ricci DR, Carere RG, Munt BI, Buller CE, Pasupati S, Lichtenstein S. Percutaneous aortic valve implantation retrograde from the femoral artery. Circulation. 2006;113:842-50.

3. Grube E, Laborde JC, Zickmann B, Gerckens U, Felderhoff T, Sauren B, Bootsveld A, Buellesfeld L, Iversen S. First report on a human percutaneous transluminal implantation of a self-expanding valve prosthesis for interventional treatment of aortic valve stenosis. Catheter Cardiovasc Interv. 2005;66:465-9.

4. Cribier A, Eltchaninoff H, Tron C, Bauer F, Agatiello C, Nercolini D, Tapiero S, Litzler PY, Bessou JP, Babaliaros V. Treatment of calcific aortic stenosis with the percutaneous heart valve: mid-term follow-up from the initial feasibility studies: the French experience. J Am Coll Cardiol. 2006;47:1214-23.

5. Grube E, Laborde JC, Gerckens U, Felderhoff T, Sauren B, Buellesfeld L, Mueller R, Menichelli M, Schmidt T, Zickmann B, Iversen S, Stone GW. Percutaneous implantation of the CoreValve self-expanding valve prosthesis in high-risk patients with aortic valve disease: the Siegburg first-in-man study. Circulation. 2006;114:1616-24.

6. Grube E, Schuler G, Buellesfeld L, Gerckens U, Linke A, Wenaweser P, Sauren B, Mohr FW, Walther T, Zickmann B, Iversen S, Felderhoff T, Cartier R, Bonan R. Percutaneous aortic valve replacement for severe aortic stenosis in high-risk patients using the second- and current third-generation self-expanding CoreValve prosthesis: device success and 30-day clinical outcome. J Am Coll Cardiol. 2007;50:69-76.

7. Godino C, Maisano F, Montorfano M, Latib A, Chieffo A, Michev I, Al-Lamee R, Bande M, Mussardo M, Arioli F, Ielasi A, Cioni M, Taramasso M, Arendar I, Grimaldi A, Spagnolo P, Zangrillo A, La Canna G, Alfieri O, Colombo A. Outcomes after transcatheter aortic valve implantation with both Edwards-SAPIEN and CoreValve devices in a single center: the Milan experience. JACC Cardiovasc Interv. 2010;3:1110-21.

8. Binder RK, Webb JG, Willson AB, Urena M, Hansson NC, Norgaard BL, Pibarot P, Barbanti M, Larose E, Freeman M, Dumont E, Thompson C, Wheeler M, Moss RR, Yang TH, Pasian S, 
Hague CJ, Nguyen G, Raju R, Toggweiler S, Min JK, Wood DA, Rodés-Cabau J, Leipsic J. The impact of integration of a multidetector computed tomography annulus area sizing algorithm on outcomes of transcatheter aortic valve replacement: a prospective, multicenter, controlled trial. J Am Coll Cardiol. 2013;62:431-8.

9. Mylotte D, Dorfmeister M, Elhmidi Y, Mazzitelli D, Bleiziffer S, Wagner A, Noterdaeme T, Lange R, Piazza N. Erroneous measurement of the aortic annular diameter using 2-dimensional echocardiography resulting in inappropriate CoreValve size selection: a retrospective comparison with multislice computed tomography. JACC Cardiovasc Interv. 2014;7:652-61.

10. Moat NE, Ludman P, de Belder MA, Bridgewater B, Cunningham AD, Young CP, Thomas M, Kovac J, Spyt T, MacCarthy PA, Wendler O, Hildick-Smith D, Davies SW, Trivedi U, Blackman DJ, Levy RD, Brecker SJ, Baumbach A, Daniel T, Gray H, Mullen MJ. Long-term outcomes after transcatheter aortic valve implantation in high-risk patients with severe aortic stenosis: the U.K. TAVI (United Kingdom Transcatheter Aortic Valve Implantation) Registry. J Am Coll Cardiol. 2011;58:2130-8.

11. Gilard $\mathrm{M}$, Eltchaninoff $\mathrm{H}$, Iung $\mathrm{B}$, Donzeau-Gouge $\mathrm{P}$, Chevreul K, Fajadet J, Leprince P, Leguerrier A, Lievre M, Prat A, Teiger E, Lefevre T, Himbert D, Tchetche D, Carrié D, Albat B, Cribier A, Rioufol G, Sudre A, Blanchard D, Collet F, Dos Santos P, Meneveau N, Tirouvanziam A, Caussin C, Guyon P, Boschat J, Le Breton H, Collart F, Houel R, Delpine S, Souteyrand G, Favereau X, Ohlmann P, Doisy V, Grollier G, Gommeaux A, Claudel JP, Bourlon F, Bertrand B, Van Belle E, Laskar M; FRANCE 2 Investigators. Registry of transcatheter aortic-valve implantation in high-risk patients. $N$ Engl J Med. 2012;366:1705-15.

12. Di Mario C, Eltchaninoff H, Moat N, Goicolea J, Ussia GP, Kala P, Wenaweser P, Zembala M, Nickenig G, Alegria Barrero E, Snow T, Iung B, Zamorano P, Schuler G, Corti R, Alfieri O, Prendergast B, Ludman P, Windecker S, Sabate M, Gilard M, Witowski A, Danenberg H, Schroeder E, Romeo F, Macaya C, Derumeaux G, Maggioni A, Tavazzi L; Transcatheter Valve Treatment Sentinel Registry (TCVT) Investigators of the EURObservational Research Programme (EORP) of the European Society of Cardiology. The 2011-12 pilot European Sentinel Registry of Transcatheter Aortic Valve Implantation: in-hospital results in 4,571 patients. EuroIntervention. 2013;8:1362-71.

13. Chieffo A, Buchanan GL, Van Mieghem NM, Tchetche D, Dumonteil N, Latib A, van der Boon RM, Vahdat O, Marcheix B, Farah B, Serruys PW, Fajadet J, Carrié D, de Jaegere PP, Colombo A. Transcatheter aortic valve implantation with the Edwards SAPIEN versus the Medtronic CoreValve Revalving system devices: a multicenter collaborative study: the PRAGMATIC Plus Initiative (Pooled-RotterdAm-Milano-Toulouse In Collaboration). J Am Coll Cardiol. 2013;61:830-6.

14. Nombela-Franco L, Ruel M, Radhakrishnan S, Webb JG, Hansen M, Labinaz M, Thompson C, Fremes S, Dumont E, DeLarochellière R, Doyle $\mathrm{D}$, Urena $\mathrm{M}$, Mok M, Ribeiro HB, Roifman I, Watkins S, Dumesnil JG, Pibarot P, Rodés-Cabau J. Comparison of hemodynamic performance of self-expandable
CoreValve versus balloon-expandable Edwards SAPIEN aortic valves inserted by catheter for aortic stenosis. Am J Cardiol. 2013;111:1026-33.

15. Abdel-Wahab M, Comberg T, Büttner HJ, El-Mawardy M, Chatani K, Gick M, Geist V, Richardt G, Neumann FJ; SegebergKrozingen TAVI Registry. Aortic regurgitation after transcatheter aortic valve implantation with balloon- and self-expandable prostheses: a pooled analysis from a 2-center experience. JACC Cardiovasc Interv. 2014;7:284-92.

16. Hamm CW, Möllmann H, Holzhey D, Beckmann A, Veit C, Figulla HR, Cremer J, Kuck KH, Lange R, Zahn R, Sack S, Schuler G, Walther T, Beyersdorf F, Böhm M, Heusch G, Funkat AK, Meinertz T, Neumann T, Papoutsis K, Schneider S, Welz A, Mohr FW; GARY-Executive Board. The German Aortic Valve Registry (GARY): in-hospital outcome. Eur Heart J. 2014;35:1588-98.

17. Athappan G, Patvardhan E, Tuzcu EM, Svensson LG, Lemos PA, Fraccaro C, Tarantini G, Sinning JM, Nickenig G, Capodanno D, Tamburino C, Latib A, Colombo A, Kapadia SR. Incidence, predictors, and outcomes of aortic regurgitation after transcatheter aortic valve replacement: meta-analysis and systematic review of literature. J Am Coll Cardiol. 2013;61:1585-95.

18. Abdel-Wahab M, Zahn R, Horack M, Gerckens U, Schuler G, Sievert H, Eggebrecht H, Senges J, Richardt G; German transcatheter aortic valve interventions registry investigators. Aortic regurgitation after transcatheter aortic valve implantation: incidence and early outcome. Results from the German transcatheter aortic valve interventions registry. Heart. 2011;97:899-906.

19. Tamburino C, Capodanno D, Ramondo A, Petronio AS, Ettori F, Santoro G, Klugmann S, Bedogni F, Maisano F, Marzocchi A, Poli A, Antoniucci D, Napodano M, De Carlo M, Fiorina C, Ussia GP. Incidence and predictors of early and late mortality after transcatheter aortic valve implantation in 663 patients with severe aortic stenosis. Circulation. 2011;123:299-308.

20. Kodali SK, Williams MR, Smith CR, Svensson LG, Webb JG, Makkar RR, Fontana GP, Dewey TM, Thourani VH, Pichard AD, Fischbein M, Szeto WY, Lim S, Greason KL, Teirstein PS, Malaisrie SC, Douglas PS, Hahn RT, Whisenant B, Zajarias A, Wang D, Akin JJ, Anderson WN, Leon MB; PARTNER Trial Investigators. Two-year outcomes after transcatheter or surgical aortic-valve replacement. N Engl J Med. 2012;366:1686-95.

21. Ribeiro HB, Webb JG, Makkar RR, Cohen MG, Kapadia SR, Kodali S, Tamburino C, Barbanti M, Chakravarty T, Jilaihawi H, Paradis JM, de Brito FS Jr, Cánovas SJ, Cheema AN, de Jaegere PP, del Valle R, Chiam PT, Moreno R, Pradas G, Ruel M, SalgadoFernández J, Sarmento-Leite R, Toeg HD, Velianou JL, Zajarias A, Babaliaros V, Cura F, Dager AE, Manoharan G, Lerakis S, Pichard AD, Radhakrishnan S, Perin MA, Dumont E, Larose E, Pasian SG, Nombela-Franco L, Urena M, Tuzcu EM, Leon MB, Amat-Santos IJ, Leipsic J, Rodés-Cabau J. Predictive factors, management, and clinical outcomes of coronary obstruction following transcatheter aortic valve implantation: insights from a large multicenter registry. J Am Coll Cardiol. 2013;62:1552-62. 
22. Barbanti $\mathrm{M}$, Yang $\mathrm{TH}$, Rodès Cabau J, Tamburino $\mathrm{C}$, Wood DA, Jilaihawi H, Blanke P, Makkar RR, Latib A, Colombo A, Tarantini G, Raju R, Binder RK, Nguyen G, Freeman M, Ribeiro HB, Kapadia S, Min J, Feuchtner G, Gurtvich R, Alqoofi F, Pelletier M, Ussia GP, Napodano M, de Brito FS Jr, Kodali S, Norgaard BL, Hansson NC, Pache G, Canovas SJ, Zhang H, Leon MB, Webb JG, Leipsic J. Anatomical and procedural features associated with aortic root rupture during balloon-expandable transcatheter aortic valve replacement. Circulation. 2013;128:244-53.

23. Leon MB, Smith CR, Mack M, Miller DC, Moses JW, Svensson LG, Tuzcu EM, Webb JG, Fontana GP, Makkar RR, Brown DL, Block PC, Guyton RA, Pichard AD, Bavaria JE, Herrmann HC, Douglas PS, Petersen JL, Akin JJ, Anderson WN, Wang D, Pocock S; PARTNER Trial Investigators. Transcatheter aortic-valve implantation for aortic stenosis in patients who cannot undergo surgery. N Engl J Med. 2010;363:1597-607.

24. Makkar RR, Fontana GP, Jilaihawi H, Kapadia S, Pichard AD, Douglas PS, Thourani VH, Babaliaros VC, Webb JG, Herrmann HC, Bavaria JE, Kodali S, Brown DL, Bowers B, Dewey TM, Svensson LG, Tuzcu M, Moses JW, Williams MR, Siegel RJ, Akin JJ, Anderson WN, Pocock S, Smith CR, Leon MB; PARTNER Trial Investigators. Transcatheter aortic-valve replacement for inoperable severe aortic stenosis. $N$ Engl J Med. 2012;366: 1696-704.

25. Smith CR, Leon MB, Mack MJ, Miller DC, Moses JW, Svensson LG, Tuzcu EM, Webb JG, Fontana GP, Makkar RR, Williams M, Dewey T, Kapadia S, Babaliaros V, Thourani VH, Corso P, Pichard AD, Bavaria JE, Herrmann HC, Akin JJ, Anderson WN, Wang D, Pocock SJ; PARTNER Trial Investigators. Transcatheter versus surgical aortic-valve replacement in high-risk patients. N Engl J Med. 2011;364:2187-98.

26. Popma JJ, Adams DH, Reardon MJ, Yakubov SJ, Kleiman NS, Heimansohn D, Hermiller J Jr, Hughes GC, Harrison JK, Coselli J,
Diez J, Kafi A, Schreiber T, Gleason TG, Conte J, Buchbinder M, Deeb GM, Carabello B, Serruys PW, Chenoweth S, Oh JK; CoreValve United States Clinical Investigators. Transcatheter aortic valve replacement using a self-expanding bioprosthesis in patients with severe aortic stenosis at extreme risk for surgery. $\mathrm{J} \mathrm{Am}$ Coll Cardiol. 2014;63:1972-81.

27. Adams DH, Popma JJ, Reardon MJ, Yakubov SJ, Coselli JS, Deeb GM, Gleason TG, Buchbinder M, Hermiller J Jr, Kleiman NS, Chetcuti S, Heiser J, Merhi W, Zorn G, Tadros P, Robinson N, Petrossian G, Hughes GC, Harrison JK, Conte J, Maini B, Mumtaz M, Chenoweth S, Oh JK; U.S. CoreValve Clinical Investigators. Transcatheter aortic-valve replacement with a selfexpanding prosthesis. N Engl J Med. 2014;370:1790-8.

28. Abdel-Wahab M, Mehilli J, Frerker C, Neumann FJ, Kurz T, Tölg R, Zachow D, Guerra E, Massberg S, Schäfer U, El-Mawardy M, Richardt G; CHOICE investigators. Comparison of balloon-expandable vs self-expandable valves in patients undergoing transcatheter aortic valve replacement: the CHOICE randomized clinical trial. JAMA. 2014;311:1503-14.

29. Sherif MA, Abdel-Wahab M, Beurich HW, Stöcker B, Zachow D, Geist V, Tölg R, Richardt G. Haemodynamic evaluation of aortic regurgitation after transcatheter aortic valve implantation using cardiovascular magnetic resonance. EuroIntervention. 2011;7:57-63. 30. Dvir D, Webb J, Brecker S, Bleiziffer S, Hildick-Smith D, Colombo A, Descoutures F, Hengstenberg C, Moat NE, Bekeredjian R, Napodano M, Testa L, Lefevre T, Guetta V, Nissen H, Hernández JM, Roy D, Teles RC, Segev A, Dumonteil N, Fiorina C, Gotzmann M, Tchetche D, Abdel-Wahab M, De Marco F, Baumbach A, Laborde JC, Kornowski R. Transcatheter aortic valve replacement for degenerative bioprosthetic surgical valves: results from the global valve-invalve registry. Circulation. 2012;126:2335-44.

31. Tuzcu EM, Kapadia SR. Selection of valves for TAVR: is the CHOICE clear? JAMA. 2014;311:1500-2. 